\section{Preparation of 'contact product' as a reagent for coagulation tests}

\section{J.-L. PÉREZ-REQUEJO ${ }^{1}$ AND G. I. C. INGRAM Depart- ment of Haematology, St Thomas' Hospital and Medical School, London}

If Celite 512 is incubated with normal plasma, an activity can then be eluted from it which corresponds to the activation of contact clotting factors XII and XI. The phenomenon was described by Waaler (1959) who called the eluate 'activation product'. The material has been in routine use in this laboratory for a number of years in the one-stage assay of factor VIII (Essien and Ingram, 1967; Hills, Ingram, and Matchett, 1970); it is also used in a screening test for defects of the 'contact' factors. The preparation of the reagent was described by Wilson, Ingram, and Hills (1971), but the technique has required further study because some batches have clotted during preparation, and excessive thrombin activity has sometimes remained in the final product. Different methods of defibrinating the starting plasma have therefore been investigated, and the effect of a final adsorption with alumina has been examined.

\section{Materials}

\section{STARTING MATERIAL}

Human citrated plasma taken into plastic equipment, stored at $-20^{\circ} \mathrm{C}$ until required. Most samples were obtained from therapeutic venesections in polycythaemia. Plasma samples were pooled to obtain convenient quantities.

THROMBIN

Lyophilized human thrombin (Lister Institute), reconstituted in saline to $50 \mathrm{u} / \mathrm{ml}$ and stored at $-20^{\circ} \mathrm{C}$

\section{FIBRINOGEN}

Lyophilized human fibrinogen (Lister Institute), reconstituted in saline to $2 \mathrm{~g} / 1$ and stored at $-20^{\circ} \mathrm{C}$.

\section{ANCROD}

Arvin (Twyford Laboratories) ampoules containing $60 \mathrm{u} / \mathrm{ml}$ solution.

\section{APROTININ}

Trasylol (Bayer) was added to the final product to a concentration of $5 \mathrm{u} / \mathrm{ml}$.

${ }^{1}$ Present address: Banco de Sangre de Carabobo, Av. de los Colegios Profesionales, Urb. Guaparo, Valencia, Venezuela.

Received for publication 25 February 1975.

\section{PHOSPHOLIPID}

Thrombofax (Ortho) was used as the phospholipid in partial thromboplastin time tests.

\section{KAOLIN}

Suspension of light kaolin, $5 \mathrm{mg} / \mathrm{ml}$ in tris buffer.

ALUMINA

Suspension of Aluminium Hydroxide Moist Gel (British Drug Houses, Ltd), suspension in tris buffer $3 \mathrm{~g} / 4 \mathrm{ml}$ diluted 1 in 50 in tris for use; one volume of the dilution was incubated for $3 \mathrm{~min}$ with 9 vol of final product, and the alumina was then removed by centrifugation.

TRIS BUFFER

$20 \mathrm{mM}, \mathrm{pH} 7 \cdot 4$ at $20^{\circ} \mathrm{C}$.

Celite 512 (Johns-Manville \& Co Ltd, London) added as solid.

CALCIUM CHLORIDE

$25 \mathrm{mM}$ solution in water.

\section{Methods}

The manipulations were carried out in plastic or $\mathbb{\perp}$ siliconized equipment. The preparation was on the lines of the description given by Wilson et al (1971); the method now recommended is given below.

DEFIBRINATION OF PLASMA BEFORE CELITE TREATMENT

A quantity of plasma was divided into four portions. One aliquot was kept as control, and the other three were defibrinated by one of the following methods:

(a) Heating at $56^{\circ} \mathrm{C}$ for $3 \mathrm{~min}$.

(b) Addition of thrombin. It was necessary to add 9 $1 \mathrm{u} / 3-4 \mathrm{ml}$ plasma for complete defibrination; $>$ the plasma was then incubated at $37^{\circ} \mathrm{C}$ for $30 \mathrm{~min}$ to allow residual thrombin to be neut- $\overline{\mathrm{N}}$ ralized.

(c) Addition of ancrod. As with thrombin, $1 \mathrm{u} / 3-4$ N $\mathrm{ml}$ plasma was found to be required.

Following these treatments the aliquots were 0 centrifuged at $2000 \mathrm{rpm}$ at $4^{\circ} \mathrm{C}$ for 20 min to harvest the defibrinated plasmas. From this point on, the $\frac{D}{\Phi}$ preparation of each aliquot followed the method of $\stackrel{\mathcal{D}}{+}$ Wilson et al (1971).

\section{Results}

DEFIBRINATION OF STARTING PLASMA

The heat technique was simple to perform; thrombin gave an intractable clot which prevented the re- 
covery of more than $75-80 \%$ of the original plasma; whereas the clot formed with ancrod was spun down to a thin layer at the bottom of the container and $95 \%$ of the original plasma volume was recovered.

The potencies of the four preparations of contact product are shown in table I. The data show the

\begin{tabular}{lll}
\hline Defibrination of & Duplicate & PTT \\
Contact Product & & \\
\hline Heat & $41 \cdot 0$ & $43 \cdot 8$ \\
Thrombin & $37 \cdot 0$ & $36 \cdot 6$ \\
Ancrod & $38 \cdot 0$ & $37 \cdot 8$ \\
None-control & $35 \cdot 2$ & $37 \cdot 0$ \\
\hline
\end{tabular}

Table I Partial thromboplastin time (PTT: $s)$ on aliquots of normal, uncontacted plasma to which had been added phospholipid, calcium chloride solution, and one of the four samples of contact product $(0 \cdot 1 \mathrm{ml}$ of each reagent)

The corresponding duplicate partial thromboplastin times after 10 min preincubation with kaolin suspension in place of contact product were $38 \cdot 6,38 \cdot 6 \mathrm{~s}$.

ability of the products to shorten the partial thromboplastin times of uncontacted normal plasma. There was a clear reduction in activity after heat defibrination, but neither thrombin nor ancrod treatments produced appreciable loss. Because of the difficulty in removing the thrombin clot, the ancrod method was preferred. The activity of the ancrod preparation was further compared with the control sample from undefibrinated plasma by repeating the tests on factor-XI deficient plasma; the results shown in table II are confirmatory.

The behaviour of the product made by ancroddefibrination was then compared with that of the product without defibrination in a one-stage factor VIII assay. Dilutions of a factor VIII standard, a normal plasma, and a partially VIII-deficient plasma were made at 1 in 10,1 in 50, and 1 in 250 in tris buffer and tested in the one-stage test as described by Wilson et al (1971) except that the

\begin{tabular}{|c|c|c|c|}
\hline \multirow{2}{*}{ Plasma Tested } & \multirow{2}{*}{$\begin{array}{l}\text { Kaolin } \\
\text { Control }\end{array}$} & \multicolumn{2}{|c|}{ Contact Product } \\
\hline & & $\begin{array}{l}\text { Defibrinated } \\
\text { with Ancrod }\end{array}$ & $\begin{array}{l}\text { Not } \\
\text { Defibrinated }\end{array}$ \\
\hline $\begin{array}{l}\text { Normal uncontacted } \\
\text { Factor-XI deficient }\end{array}$ & $\begin{array}{l}38 \cdot 2 \\
61 \cdot 8\end{array}$ & $\begin{array}{l}33 \cdot 3 \\
26 \cdot 8\end{array}$ & $\begin{array}{l}33 \cdot 7 \\
27 \cdot 6\end{array}$ \\
\hline
\end{tabular}

Table II Partial thromboplastin time (s) on aliquots of normal, uncontacted plasma and factor-IX deficient plasma in the standard method with 10 min preincubation with kaolin, and with replacing the kaolin by ancrod-defibrinated contact product and by contact product made from plasma without defibrination

\begin{tabular}{lll}
\hline Test Plasma & \multicolumn{2}{l}{ Contact Product } \\
\cline { 2 - 3 } & $\begin{array}{l}\text { Defibrinated with } \\
\text { Ancrod }\end{array}$ & Not Defibrinated \\
\hline Factor VIII deficient & 0.21 & 0.23 \\
Normal & 0.91 & 1.06 \\
\hline
\end{tabular}

Table III Factor VIII activity (iu/ml) determined in one-stage assays with contact products made from ancrod-defibrinated plasma and plasma without defibrination

haemophilic ('substrate') plasma was added first to the tubes, then the dilutions to be tested, and then the phospholipid. Thereafter each tube received calcium chloride solution and then contact product, immediately before testing. The potencies obtained for the two test plasmas with each sample of contact product are given in table III, which shows no substantial difference between contact products for either test plasma.

\section{THROMBIN ACTIVITY}

Three aliquots of the preparations of contact product made without defibrination and after ancroddefibrination were taken: one sample from each product was adsorbed with alumina gel, another pair of samples received aprotinin to $5 \mathrm{u} / \mathrm{ml}$, and the third pair served as a control. Volumes of $0.1 \mathrm{ml}$ of each sample were mixed with $0.3 \mathrm{ml}$ vols of a fibrinogen solution $0.5 \mathrm{~g} / \mathrm{l}$, and incubated at $37^{\circ} \mathrm{C}$. Both control samples and both those containing aprotinin had clotted after $1 \mathrm{hr}$; the adsorbed sample made without defibrination had clotted after $2 \mathrm{hr}$; but the adsorbed sample from the ancrod-treated plasma remained unclotted after $6 \mathrm{hr}$.

\section{FIBRINOLYTIC ACTIVITY}

Aliquots of $0.1 \mathrm{ml}$ of the six samples tested in the preceding section were mixed with $0.3 \mathrm{ml}$ of the fibrinogen solution $0.5 \mathrm{~g} / \mathrm{l}$ and clotted with thrombin. The clots were observed at $37^{\circ} \mathrm{C}$ for $72 \mathrm{hr}$ and no dissolution occurred. It was therefore concluded that the preparations were without significant fibrinolytic activity.

\section{STABILITY ON STORAGE}

A batch prepared by the proposed method was tested on seven occasions over a period of 205 days' storage at $-30^{\circ} \mathrm{C} .0 .1 \mathrm{ml}$ vols of pooled, noncontacted normal plasma and Thrombofax were incubated together for $3 \mathrm{~min}$ and then $0.1 \mathrm{ml}$ vols of $\mathrm{CaCl}_{2}$-solution and contact product were added and the clotting time was recorded; each test was made in duplicate. The mean clotting times showed 
a significant regression on time $\left(t_{6}=2.52 ; 0.05>\right.$ $P>0.02$ ), prolonging at a rate of $2.6 \mathrm{~s} / 100$ days; in practice the rate of deterioration, however, has not been found to interfere with the use of the product, and batches usually last for about six months. Repeated freezing and thawing does not appear significantly to hasten deterioration.

\section{Modified Preparation of 'Contact Product'}

Plastic or siliconized material must be used throughout.

Normal human citrated non-contacted plasma, for example from outdated bank blood in plastic bags or from therapeutic venesections, may be stored frozen. For the preparation, a convenient quantity is brought to $37^{\circ} \mathrm{C}$ in the water bath, and undiluted ancrod is then added to a concentration of $1 \mathrm{u} / 3-4 \mathrm{ml}$ plasma; rapidly invert three times to mix and then let the plasma stand in centrifuge bottles or tubes for $20 \mathrm{~min}$. Centrifuge at $4^{\circ} \mathrm{C}$ at $\mathrm{ca} 2000 \mathrm{~g}$ for $20 \mathrm{~min}$. Collect the supernatant plasma and mix with Celite $512,2 \mathrm{~g} / 100 \mathrm{ml}$, and incubate at $37^{\circ} \mathrm{C}$ for $10 \mathrm{~min}$ with occasional mixing. Centrifuge at $4^{\circ} \mathrm{C}$ at $\mathrm{ca} 2000 \mathrm{~g}$ for $20 \mathrm{~min}$ or as necessary to deposit the Celite. Discard the supernatant and wash the precipitate three times in chilled saline by resuspension and recentrifugation; resuspension of the Celite is conveniently achieved by stirring with a chisel-ended Perspex rod of $c a 1 \mathrm{~cm}$ diameter. Finally, elute the precipitate by suspension in oneeighth of the starting plasma volume of $7 \% \mathrm{NaCl}$ in $12.5 \mathrm{mM}$ tris at $37^{\circ} \mathrm{C}$ and incubate for $10 \mathrm{~min}$ with occasional stirring. Remove the Celite by centrifugation at $4^{\circ} \mathrm{C}$ and dialyse the supernatant overnight at $4^{\circ} \mathrm{C}$ against $10 \times$ vol $0.5 \mathrm{mM}$ tris containing that quantity of sodium chloride calculated to yield $0.85 \%$ after equilibration. After dialysis add aprotinin $5 \mathrm{u} / \mathrm{ml}$ contact product. Lastly adsorb the product with alumina gel by adding 1 vol of the 1 in 50 suspension described to 9 vol product and incubate for $3 \mathrm{~min}$ at $37^{\circ} \mathrm{C}$; remove the alumina by centrifugation and freeze the product in suitable volumes in stoppered plastic tubes for storage at $-30^{\circ} \mathrm{C}$, after the following quality checks have been satisfied.

QUALITY CHECKS FOR EACH BATCH

1 Test for the presence of thrombin by incubating $0.1 \mathrm{ml}$ of product with $0.3 \mathrm{ml}$ of fibrinogen solution $0.5 \mathrm{~g} / \mathrm{l}$ and inspect at $15 \mathrm{~min}$ intervals for clot formation. No clot should appear for $6 \mathrm{hr}$; if clotting occurs within this time, repeat the alumina adsorption step.

2 Test for fibrinolytic activity by mixing a $0.1 \mathrm{ml}$ aliquot with $0.3 \mathrm{ml}$ of fibrinogen solution $0.5 \mathrm{~g} / \mathrm{l}$ and clot with thrombin, and observe the clot for
5-6 hr at $37^{\circ} \mathrm{C}$ for dissolution; no change in the clot should be apparent over this period.

3 Test the 'contact' activity as follows. Obtain $\stackrel{\vec{F}}{\stackrel{(}{+}}$ sample of fresh, non-contacted normal citratede plasma and perform the partial thromboplastin time $\frac{\bar{\sigma}}{\bar{c}}$ after 10 min preincubation with an equal vol of kaolin suspension. Repeat the test with a further aliquot ${ }^{\circ}$ of the plasma to which have been successively addedes $0.1 \mathrm{ml}$ of phospholipid, calcium chloride solution, $\overrightarrow{0}$ and the contact product. The clotting time with the product should not exceed $40 \mathrm{sec}$; if the time is $\vec{\omega}$ shorter than that obtained with kaolin, the product may be diluted with tris until an equal time is obtained.

Finally, the product, adjusted as necessary as a- $v$ result of the above tests, should be compared with kaolin activation of severely factor-VIII and factor-o IX deficient plasmas. Approximately the same? partial thromboplastin times should be obtained by $\vec{c}$ kaolin activation and with the product on each plasma. Partially deficient factor-VIII and factor-IX plasma samples should then be assayed for factor $\stackrel{\oplus}{-}$ VIII and factor IX respectively with the product ${ }^{\mathrm{V}}$ and by the previous routine method (kaolin, or an? earlier batch of 'contact product'), and similars results should be obtained.

\section{Use of 'Contact Product'}

As mentioned above, the use of 'contact product' in factor-VIII and factor-IX assays has been modified 3 from the technique described by Wilson et al (1971) by diluting the test samples in tris instead of in theo substrate plasma, and by adding the contact product, instead of the calcium chloride, as the las $\mathrm{l}^{\mathrm{O}}$ reagent from whose addition the clotting is timed $\frac{5}{3}$ This latter modification was found to reduce then experimental error, because it has been observed? that when the 'contact product' was added before the calcium chloride, a delay in adding the calcium? chloride led to a shortening of the clotting time. $\frac{7}{0}$

The use of contact product in a screening test for defects of the 'contact factors' has been described in the paper by Ingram, Knights, Arocha-Piñango Shepperd, and Pérez-Requejo (1975).

\section{References}

Essien, E. M. and Ingram, G. I. C. (1967). Diagnosis of haempohilia: use of an artificial factor-VIII-deficient human plasma system. J. clin. Path., 20, 620-623.

Hardisty, R. M. and Ingram, G. I. C. (1965). Bleeding, Disorders: Investigation and Management, p. 313. Black $\frac{O}{\mathrm{D}}$ well, Oxford.

Hills, M., Ingram, G. I. C., and Matchett, M. O. (1970) Lyophilized plasma as an assay standard for factor VIII :calibration and control with fresh plasma samples. Brit J. Haemat., 18, 617-624. 
Ingram, G. I. C., Knights, S. F., Arocha-Pinango, C. L., Shepperd, J. P., and Pérez-Requejo, J. L. (1975). Simple screening tests for the diagnosis of isolated clotting factor defects. J. clin. Path., 28, 524-530.

Waaler, B. A. (1959). Contact activation in the intrinsic blood clotting system. Scand. J. clin. Lab. Invest., 11, Suppl. 37, pp. 53-57.

Wilson, W. J., Ingram, G. I. C., and Hills, M. (1971).

The use of kaolin or contact product in the one-stage assay of factor VIII. Coagulation, 4, 113-117.

\section{Letters to the Editor}

\section{Liver-cell Mass and Nuclear-cytoplasmic Ratio in Human Liver}

In spite of current interest in histoquantitation, reflected in your issue of February 1975 , there is as yet little information on measurement of tissue components of mammalian liver under the microscope, and figures cited vary widely. Thus, for instance, hepatocyte cytoplasm is said to account for $77 \%$ of liver volume in the rat (Weibel et al, 1969) while in man about $60 \%$ of the liver is said to be composed of liver cells (Sherlock, 1968).

We have recently calculated figures for formalin-fixed, paraffin-embedded liver biopsies on the basis of point-count morphometry. The work formed part of a thesis presented by one of us (LCCG) for the degree of $\mathrm{PhD}$ in the University of London. Liver cells in 20 normal human livers accounted for $80.5 \pm 4.2 \%$ of total volume (mean $\pm \mathrm{SD}$ ). Liver-cell cytoplasm alone accounted for $70.9 \pm 4.5 \%$ and nuclei for $9.6 \pm 1.9 \%$. The latter figures give a mean nuclear-cytoplasmic ratio of approximately 0.14 or $1: 7$. Our results suggest that liver cells form an even larger proportion of human liver than was previously supposed.

$$
\begin{array}{r}
\text { LUIZ CARLOS C. GAYOTTO } \\
\text { PETER J. SCHEUER } \\
\text { Department of Histopathology, } \\
\text { Royal Free Hospital, } \\
\text { Pond Street, } \\
\text { London NW3 } 2 Q G
\end{array}
$$

\section{References}

Sherlock, S. (1968). Diseases of the Liver and Biliary System, 4th ed., p. 10. Blackwell, Oxford.

Weibel, E. R., Stäubli, W., Gnägi, E. R., and Hess, F. A. (1969). Correlated morphometric and biochemical studies on the liver cell. I Morphometric model, stereologic methods, and normal morphometric data for rat liver. J. cell. Biol., 42, 68-91.

\section{Correction to Error}

Anderson, J. D., Lacey, R. W., Lewis, E. L., and Sellin, M. A. (1974). Failure to demonstrate an advantage in combining sulphamethoxazole with trimethoprim. J. clin. Path., 27, 619-22.

The above paper contains two transscription errors, one of which appears to invalidate the conclusions in the text. Table II, column 3, line 4 (sulphamethoxazole in urine): for 0 read 1; Table II, column 3 , line 12 : for $(0.01 \rightarrow 6.3)$ read $(0.11 \rightarrow 6.3)$.

J. D. ANDERSON
Department of Microbiology,
District Laboratory,
County Hospital,
Monkgate,
York YO3 7PG.

\section{Book reviews}

The Acid-Base Status of the Blood. 4th Edition. By Ole Siggaard-Andersen. (Pp. xii + 229; illustrated; Dan. Kr. 으 110:00.) Copenhagen: Munksgaard. 1974.

This book is something of a tour-de-force. It will be of the greatest scientific value $\vec{\varphi}$ to those trying to master the complexity of all the known factors concerned in acid-base blood chemistry. The author stresses mathematical and chemical exactness and this makes for very heavy going on the part of all who cannot describe themselves as physical chemists.

Nevertheless, this book should be $a$ valuable comprehensive addition to the $\underline{O}$ library of a clinical chemist. The sections on analytical methods are quite superb, and the sources of error are clearly outlined. The bibliography is excellent.

Atlas of Human Glomerular Pathology. By Peter M. Burkholder. (Pp. 44; 100 figures; \$35.00.) New York and London: Harper and Row. 1974.

In recent years advances in both experi- $\frac{D}{2}$ mental and human renal pathology have been rapid. Renal biopsy techniques $\sigma$ have been improved and it is now manda- $N$ tory in most centres for histological $N$ examination of kidney tissue to include $\omega$ immunofluorescence and electron microscopy as well as conventional light $\mathscr{O}$ microscopy. The appearance of this atlas $\Phi$ is thus timely and, coming from one who $\stackrel{?}{+}$ has himself contributed much to our 7 present understanding of renal disease, it is authoritative as well. A chapter is devoted to each of the main glomerulo- $\overrightarrow{\mathbb{D}}$ pathies, and the illustrations of the light $\varrho$ microscopic, immunofluorescent, and ultrastructural findings are clear and o informative. Each chapter begins with a 